www.jmscr.igmpublication.org Impact Factor 5.84

Index Copernicus Value: 83.27 ISSN (e)-2347-176x ISSN (p) 2455-0450 crossref DOI: _https://dx.doi.org/10.18535/jmscr/v5i4.51

\title{
The Study of Clinico-Pathological Condition of Acute Appendicitis In Srikakulam
}

\author{
Authors \\ Suraj Kumar Patnaik ${ }^{1}$, S.S.N.Moulika ${ }^{2}$, N.Ravi Kiran ${ }^{3}$
}

\begin{abstract}
Object: To study clinical and pathological presentation, management and outcome of appendicitis

Methodology: During 2 years study period. We studied 100 cases of acute appendicitis admitted in Rajiv Gandhi institute of medical \& general Hospital srikakulam. out of them 97 case are appendicitis and 3 were other causes A detailed history and through clinical examination was done the diagnosis of Appendicitis was based upon Alvarado Score, Total W.B.C. count and ultrasonography and Histopathological examination.

Results: The study group consisted of 100 patients. Majority (62\%) of patients were males and (38\%) was Females most, common symptoms were pain in the right iliac fossa 98\%, anorexia in $88 \%$, Nausea $87 \%$ and Vomiting 83\%, Total leucocyte count $>10.000$ in 50\%, of patients, and USG findings of localized adynamic illeus in $88 \%$, and Alvarado Score 7 or $>7$ are $90 \%$ and Histopathology $89 \%$ the overall negative appendicitis of $16.7 \%$ in female and $3.8 \%$ in Males.

Conclusion: Thus from above findings, it can be concluded early diagnosis and appendicectomy is mandatory for better outcome of the patients. The definitive appendicectomy is the line of management.

Keywords: Appendicitis; Alvarado Score; Ultrasonography;
\end{abstract}

\section{Introduction}

It is a well-known adage that abdomen is a temple of surprises and a magic box as well. Since the abdomen accommodates innumerable viscera and other anatomical compliments, diseases of the abdomen constitute a topic full of clinical curiosity. A meticulous examination of abdomen is one of the most rewarding diagnostic procedures available to the doctor, especially the surgeon and plans an ideal treatment. As had been said by Bailey "A correct diagnosis is the hand maiden of successful operation". Despite the advancements in the fields of diagnosis the surprises never Cease $^{(1)}$.The appendix a cul-de-sac is crudely referred as "worm of the bowel" in ancient medical books and also called as abdominal tonsil". Acute appendicitis is the most common acute surgical condition of the abdomen Approximately 7 percent of the population will have appendicitis in there life time ${ }^{(3)}$, with the peak incidence occurring between 10 and 30 years $^{(4)}$. Despite technological advances the diagnosis of appendicitis is still based primarily on the patients history and the physical examination, prompt diagnosis and surgical referral may reduce the risk of perforation and prevent complications ${ }^{(5)}$. The mortality rate in non-perforated appendicitis is less than 1 percent, but it may be as high as 5 percent or more in young and elderly patients in whom the diagnosis 
may often be delayed thus making perforation more likely ${ }^{(2)}$. Preoperative diagnosis of acute appendicitis is sometimes challenging in young women, children and aged despite all round improvements in medical field and ultrasonography. Diagnostic scores are useful easy methods, which help to reach in decision-making. Delay in diagnosis will lead to complication, which increases morbidity where as overzealous diagnosis may lead to negative appendicectomy rate

This study involves to correlate the acute appendicitis between clinically diagnosed and histopatologically examined specimen and the role of ultrasound in early diagnosis of acute appendicitis and to exclude negative appendicectomy, in patents admitted in Rajiv Gandhi institute of medical \& general Hospital srikakulam during the period Februar 2015 to February 2017.

\section{Methodology \\ Source of Data}

For the study, the patients admitted with Acute Appendicitis in Emergency and surgical wards in all the units Rajiv Gandhi institute of medical \& general Hospital srikakulam are included without bias on a serial basis. This is a randomised study comprising of 100 patients of suspected acute appendicitis over a period of two years (i.e. from February 2015 to February 2017.). The patients on admission with suspected acute appendicitis are evaluated on the basis of Alvarado Scoring System.

\section{Inclusion Criteria}

All patients who are coming to surgical OPD at Government General Hospital and Basaveshwar Teaching \& General Hospital, Gulbarga with Complaints of Acute pain in the right iliac fossa.

\section{Exclusion Criteria}

All patients other than acute Appendicitis are excluded.

A proforma was made for the study of these cases. The cases are subjected to a detailed clinical examination and essential investigations namely total white cell count and ultrasonography of abdomen.

\section{USG Criteria of Acute Appendicitis}

- Visualisation of appendix, Diameter $>6 \mathrm{~mm}$, Wall thickness $>3 \mathrm{~mm}$, Complex mass (echo poor, asymmetric), Irregular asymmetry, Loss of contour, Free fluid, Local adynamic ileus, Graded tenderness over Mc Burney's point.

Patients with score of 1-4 are not considered likely to have acute appendicitis; those with score of 5-6 probably have, those with score of 7-8 possibly have, those with score of 9-10 are considered to have definitive diagnosis.

\section{Scoring System}

$\begin{array}{lll}1-4 & - & \text { Appendicitis unlikely } \\ 5-6 & - & \text { Appendicitis possible } \\ 7-8 & - & \text { Appendicitis probable } \\ 9-10 & - & \text { Appendicitis definitive }\end{array}$

Patients with score of 7 and $>7$ are subjected to surgery. Operative and histopathological diagnoses of appendicitis are confirmed. The cases subjected to emergency surgery are adequately prepared by parenteral fluids, electrolyte supplementation, administration of broad spectrum antibiotics intravenously (usually combination of Ciplox $200 \mathrm{mg} \mathrm{12}$ th hourly + Gentamycin $80 \mathrm{mg}$ 12 hourly + Metronidazole $500 \mathrm{mg} 8^{\text {th }}$ hourly). Surgery was done under spinal anesthesia. Grid iron incision was employed in all cases. Post operatively patients are kept nil orally, till bowel sounds returned, parenteral fluid, electrolytes, antibiotics and analgesics were continued. Cases are watched for any post operative complications and treated wherever needed. Post operatively sutures are removed on 7-9 days and the patients were discharged afterhistopathological confirmation

\section{Results}

In this series of 100 cases, all the patients who presented with acute symptoms and diagnosed to have acute appendicitis were included in the study. 
Table - 1: Age and Sex Incidence:

\begin{tabular}{|l|c|c|}
\hline \multirow{2}{*}{ Age Group (Years) } & \multicolumn{2}{|c|}{ Sex } \\
\cline { 2 - 3 } & Male=62 & Femalen=38 \\
\hline $1-10$ & 2 & 1 \\
\hline $11-20$ & 26 & 16 \\
\hline $21-30$ & 28 & 18 \\
\hline $31-40$ & 6 & 3 \\
\hline $41-50$ & -- & -- \\
\hline
\end{tabular}

Acute appendicitis is more common in males than females. Boyd discussing acute appendicitis disease says it is more than twice as common in males as in females and explains it may be due to fact that young males is more subject to strain and trauma and that his diet is usually richer in protein than that of the females. In our series the male to female ratio is 3.1:1.9 In Levis et al series of 1000 cases, the incidence of acute appendicitis was found to occur most commonly in the age group of 20-30 years in both males and females. The male to female ratio was 3:2.In our series, the maximum incidence as found in the age group of 20 to 30 years.

Table -2: USG Findings

\begin{tabular}{|l|c|c|}
\hline USG Findings & $\begin{array}{c}\text { No of Patients } \\
\mathrm{n}=100\end{array}$ & Percentage \\
\hline Visualization of appendix & 33 & 33.00 \\
\hline Diameter $>6 \mathrm{~mm}$ & 6 & 6.00 \\
\hline Wall Thickness $>3 \mathrm{~mm}$ & 22 & 22.00 \\
\hline Irregular asymmetry & -- & -- \\
\hline Loss of contour & -- & -- \\
\hline Free fluid over & 88 & -- \\
\hline Local adynamic ileus & 88 & 88.00 \\
\hline $\begin{array}{l}\text { Graded tenderness } \\
\text { McBurney's point }\end{array}$ & 12 & 12.00 \\
\hline Normally study & & \\
\hline
\end{tabular}

In 90 patients, 54 were males and 36 were females with a score of 7 and more than 7. all of them were subjected to surgery with confirmation in 52 out of 54 males -

$96.2 \%$ and 30 out of 36 females $-83.3 \%$. The negative appendicectomy rate of males is

$3.8 \%$ and in females $16.7 \%$. Women with normal appendix who underwent operation were having pelvic inflammatory disease in 5 patients, and ruptured follicular cyst in 1 patient. One of the males with normal appendix had Meckels diverticulities while the other had regional ileitis. 90 patients were given spinal anesthesia and 7 were given general anesthesia.

Incision: The incision commonly employed was grid-iron incision and was extended whenever posed with difficulties and better exposure was needed. In one case, the appendix was normal and a Meckel's diverticulum was present. Appendicectomy with excision of Meckel's diverticulum was done. The position and condition of the appendix noted intra-operatively.

\section{Graph-1 Showing the Alvarado Score}

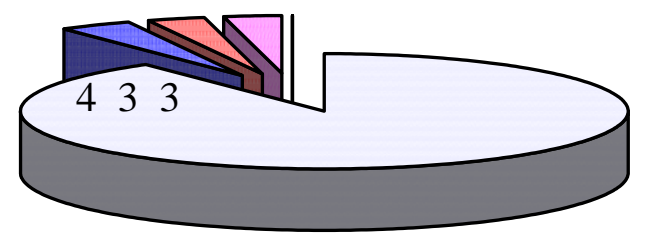

$\square \quad \square$

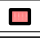

$\square$ ㅁ

90

7 or $>7 \quad$ Score of $6 \quad$ Score of $5 \quad$ Score of 4

\section{Position of Appendix}

Retocaecal................................61

Pelvic....................................20

Subcaecal.................................. 8

Paracaecal.....................................5

Preileal and post ileal........................ 3

Table - 3: The condition of The Appendix

\begin{tabular}{|l|c|c|}
\hline Condition & $\begin{array}{c}\text { No. of Patients } \\
\mathrm{n}=97\end{array}$ & Percentage \\
\hline Normal & 11 & 11.34 \\
\hline Congested & 3 & 3.09 \\
\hline Inflamed & 75 & 77.31 \\
\hline Gangrenous & 2 & 2.06 \\
\hline Perforated & 6 & 6.18 \\
\hline
\end{tabular}

In Semsi et al series of 100 emergency apendicecetomy, $21 \%$ of the patients had perforated appendix. In Martin Breumen (1970) 
series perforated appendix constituted $84 \%$ of appendicectomy and gangrenous 9.9\%.In 94.84\% (92) of patients, classical apendicectomy with burying of the appedicular stump in caecum was done. In $5.16 \%$ ( 5) cases invagination was not possible because of friable base or caecal congestion and inflammation.

The post operative complication in our series is wound infection with a percentage of

$5 \%$ or 5 patients. The pathological diagnosis of the specimen of the appendix sent for histopathological study are as follows:

Table -4 : Histopathology Reports

\begin{tabular}{|l|c|c|}
\hline Histopathology & $\begin{array}{c}\text { No. of Patients } \\
\mathrm{n}=97\end{array}$ & Percentage \\
\hline Normal & 11 & 11.34 \\
\hline Acute appendicitis & 57 & 58.76 \\
\hline $\begin{array}{l}\text { Acute suppurative } \\
\text { appendicitis }\end{array}$ & 27 & 27.83 \\
$\begin{array}{l}\text { Acute gangrenous } \\
\text { appendicitis }\end{array}$ & 2 & 2.07 \\
\hline
\end{tabular}

\section{Discussion}

The discussion is based on the observations and analysis of the results in the study of 100 cases with regard to incidence, age, sex, symptoms, signs, investigations operative findings, and histopathological examinations using Alvarado scoring system.

\section{Clinical Features}

Age incidence: In the present study the common age group found was 20.30 year $(46 \%)$ and the median age being 24 years. Gallendo Gallego et al $^{(7)}$ found was 20-30 yr(52\%)

Sex Incidence: It has been established beyond doubt by several authors, that male Sex predominated over female in the incidence of acute appendicitis. Levis et al ${ }^{(8)} \mathrm{M}: \mathrm{F}: 3: 2, \mathrm{P}$. Ronan ' $\mathrm{O}$ ' connel et al ${ }^{(9)} \mathrm{M}: \mathrm{F}: 3: 2$, Addis DG, et $\mathrm{al}^{(3)} \mathrm{M}: \mathrm{F}$ 1. 3: 1 .In Present Study M: F Ratio : 3. 1: 1.9. Out of 100 Cases, there were 62 Male patients $(62 \%)$ and 38 Female patients $(38 \%)$ Symptoms and Signs.
Pain: Pain was a complaint in all the cases in this study. The initial location of pain in most cases (59\%) presented with pain around umbilicus followed by $(41 \%)$ in the right lower quadrant and $98 \%$ of the patients lately presented with pain in the right iliac fossa, which adds a diagnostic point of acute Appendicitis.

Table -5 Pain By Various Authors.

\begin{tabular}{|l|c|c|c|}
\hline Authors & $\begin{array}{c}\text { Pain } \\
\text { around } \\
\text { Umbilicus }\end{array}$ & $\begin{array}{c}\text { Pain right } \\
\text { lower } \\
\text { quadrant }\end{array}$ & $\begin{array}{c}\text { Pain in the } \\
\text { Right iliac } \\
\text { fossa }\end{array}$ \\
\hline $\begin{array}{l}\text { Gallindo Gallego } \\
\text { et al }\end{array}$ & $49 \%$ & $32 \%$ & $96.4 \%$ \\
\hline Schwartz SI $^{4}$ & $50 \%$ & $50 \%$ & $100 \%$ \\
\hline Present Study & $59 \%$ & $41 \%$ & $98 \%$ \\
\hline
\end{tabular}

Anorexia: Anorexia was present in $88 \%$ of patients in present series. Anorexia nearly always accompanies appendicitis. In present study it is $88 \%$ and in previous study Kallan $\mathrm{M}$ et al $85 \%$ George Mathews, et al ${ }^{(10)} 92.13 \%$

Nausea or Vomiting: Nausea was present in $87 \%$ of Cases and vomiting in $83 \%$ of cases in present series.

Table- 6: Nausea or vomiting as a symptom.

\begin{tabular}{|l|c|c|}
\hline Authors & Nausea & Vomiting \\
\hline Owen Td, et al & $84 \%$ & $78 \%$ \\
\hline George Mathew set al $^{(10)}$ & $92 \%$ & $70.9 \%$ \\
\hline Schwartz SI ${ }^{(4)}$ & $90 \%$ & $75 \%$ \\
\hline Present Study & $87 \%$ & $83 \%$ \\
\hline
\end{tabular}

Right Illiac fossa tenderness: Right iliac fossa tenderness was present in all the cases $100 \%$ at the time of presentation, a major contribution for diagnosis of Acute Appendicitis. In the Present Study $100 \%$ and in previous study P.K. Bhattacharjee et al ${ }^{(12)} 92 \%$, Gallindo Gallego, et al ${ }^{(13)} 94 \%$

Rebound Tenderness: In the present series, in $44 \%$ of the cases there was presence of rebound tenderness, and this is noted when there is local peritoneal involvement and it depends upon the time of presentation. In the Present Study $44 \%$ 
and in previous study P.K. Owen Td et al ${ }^{(14)} 60 \%$, GallindoGallego,et $\mathrm{al}^{(13)} 56 \%$.

Fever: Fever was present in 48 cases $(48 \%)$ in present series in the major of cases fever was of low grade and continues: the incidence of fever in the Literature and the present series is compared in the following tables. In the Present Study $48 \%$ and in previous study Kallan $M$ et al ${ }^{(15)} 40 \%$, Gallindo Gallego, et $\mathrm{al}^{(13)} 74 \%$

Leucocyte count: W.B.C. count more than 10.000 cells/ cumm was found in $50 \%$ of cases and only $2 \%$ it was raised above 20,000 Cells/ cumm.

Table 7: Leucocyte count by various authors.

\begin{tabular}{|l|c|c|}
\hline Authors & $\begin{array}{c}\text { Percentage>10.000 } \\
\text { Cells./ Cumm. }\end{array}$ & $\begin{array}{c}\text { Percentage > 20,000 } \\
\text { Cells/Cumm. }\end{array}$ \\
\hline Peiper et al & 60.00 & 5.00 \\
\hline $\begin{array}{l}\text { GallindoGallego,et } \\
\text { al }^{(13)}\end{array}$ & 65.00 & 3.00 \\
\hline Elangovan's $^{(17)}$ & 80.00 & - \\
\hline Doraiswamy & 42.00 & - \\
\hline Present Study & 50.00 & 2.00 \\
\hline
\end{tabular}

Ultrasonography: In the present series Visualisation of appendix was only seen in 33\% of the patients. The reasons is due to non availability of high frequency probe.

In a study by Puylaert BCM et all $88.5 \%$ of the patients on ultrasound were reported Visualisation of the appendix in another study by Gallindo Galligoetal ${ }^{(13)} 82 \%$ of the patients reported with Visualisation of appendix. In the present series, graded tenderness over the McBurney's point by transducer was $88 \%$ which is the good diagnostic feature of acute appendicitis. According to Puylaert BCM et al graded tenderness over the McBurney's by transducer was $89 \%$ in the present series $88 \%$ of patients are reported as local dynamic illus in ultrasound. The raise of percentage may be due to other pathologies which also show illus other than appendicitis. In the present series $12 \%$ of the patients were reported as normal study of ultrasound and use has a role excluding the diagnosis of acute appendicitis.

USG specificity and sensitivity in diagnosis of acute appendicitis:

In the present study USG findings showed $88 \%$ sensitivity and $88 \%$ specificity in diagnosing acute appendicitis.

Table 8: Value of USG in the diagnosis of acute appendicitis.

\begin{tabular}{|l|c|c|}
\hline Authors & Specificity & Sensitivity \\
\hline George Mathews et al & $90.90 \%$ & $88.13 \%$ \\
\hline Puylaert JBCM et al $^{19}$ & $100 \%$ & $89 \%$ \\
\hline Gallindo Gallego et al & $82 \%$ & $89 \%$ \\
\hline Jeffrey et al & $96.2 \%$ & $89.9 \%$ \\
\hline Present Study & $88 \%$ & $88 \%$ \\
\hline
\end{tabular}

Alvorado Score: In this series $87 \%$ are Males and $94.7 \%$ were females of score 7 or more than 7 .

Table- 9: Alvarado Score 7 or $>7$ by Authors.

\begin{tabular}{|c|c|c|}
\hline Authors & \multicolumn{2}{|c|}{ Percentage } \\
\hline & Male & Female \\
\hline Bhattacharjee et al ${ }^{12}$ & 84.5 & 80.00 \\
\hline Sudhir Kumar Mohantv et al ${ }^{21}$ & 75.00 & 88.23 \\
\hline Present Study & 87.00 & 94.7 \\
\hline
\end{tabular}

Histopathology: In the present series $88.65 \%$ (86) of the patients are histopathologically confirmed and by other authors it is George Mathews et $\mathrm{al}^{30} 84 \%$, Bhatacharjeee et al ${ }^{(12)} 82 \%$ .To prove accuracy of scoring, ultrasound sensitivity and specificity histopathological confirmation is needed.

Negative Appendicectomy Rate: The present study shows negative Appendicectomy rate of $16.7 \%$ in females and $3.8 \%$ in male. In females, negative appendicectomy rate is high. This is probably due to pelvic inflammatory diseases, and ruptured follicular cysts. The conditions are not properly diagnosed on ultrasound and mimic acute appendicitis. 
Table - 10 : Negative Appendicectomy rate by various Authors.

\begin{tabular}{|l|c|c|}
\hline Authors & \multicolumn{2}{|c|}{ Percentage } \\
\hline & Male & Female \\
\hline Sudhir Kumar Mohanty et al & 4.8 & 6.7 \\
\hline Bhattachariee et al $^{12}$ & 6.9 & 19.1 \\
\hline Korner H et al $^{21}$ & 9.3 & 22.2 \\
\hline Present Study & 3.8 & 16.7 \\
\hline
\end{tabular}

\section{Conclusion}

The Alvarado scoring system combined with ultrasound can therefore be used as a cheap and inexpensive way of confirming acute appendicitis thus reducing negative appendicectomy rate. History and clinical examination was more diagnostic. Ultrasonography increases the diagnostic accuracy in patients with suspected acuter appendicitis to the tune of 9095\%.Alvarado score with less than 6 leads to more than $25 \%$ negative appendicectomy rate. If the scoring is above 7, the overall accuracy of diagnosis of acute appendicitis gives up to $90 \%$.

\section{Summary}

A study of 100 cases who presented with pain in right iliac fossa was conducted at Rajiv Gandhi institute of medical \& general Hospital srikakulam during the period February 2015 to February 2017.Emergency appendicectomy constituted $23.3 \%$ of the total abdominal surgeries. Acute appendicitis is more common in males than females and the highest incidence is in $2^{\text {nd }} \& 3^{\text {rd }}$ decade of life. The patients presented with symptoms of pain in RIF, vomiting or nausea, anorexia, and sings of RIF tenderness, rebound tenderness, and rise in temperature. The patients were examined clinically thoroughly by using Alvarado scoring system. The patients are subjected to investigations like total count and ultrasonography which are considered in the score.

Ultrasonography has diagnosed $88 \%$ of cases as acute appendicitis. 90 of the total cases which has score 7 and $>7$ were managed surgically and the remaining 7 patients with score of 6 and 5 were operated and 3 were managed conservatively. $90 \%$ of the cases were confirmed intra-operatively and $89 \%$ of histopathological examinations confirmed the diagnosis of acute appendicitis. Complications like wound infection was seen only in $5 \%$ of the patients.

\section{References}

1. Hamilton Bailey's Emergency Surgeries. $12^{\text {th }}$ Edition.,1995; 438-451.

2. Liu CD, Mcfadden DW, Acute abdomen and appendix, In: Greenfield IJ, etal., eds. Surgery : Scintific Principles and practice. $2^{\text {nd }}$ ed.Philadelphia: Lippincott-Raven, 1997: 126-1261.

3. Addis DG, Shaffer N, Fowler BS, Tauxe RV, The epidemiology of appendicits and appendicectomy in the United States, AmJ epidemiol 1990:132:910-925.

4. Schwartz SI, Appendix, In: Schwartz SI, ed, Principles of Surgery, $6^{\text {th }}$ ed. New york: Megraw Hill, 1994:1307-1318.

5. Wilcox RT, TraverSo LW, Have the evaluation and Treatment of acute appendicitis changed withnew technology ?Surg clin North Am1997:77:1355-1317.

6. Ramirez JM, Dews J : Practical Score to a decision making in doubtful cases of acute appendicitis : Br.J.S.,81:680-683,1994.

7. GallindoGallego, Fadrique, Neto, Calleja, Fernandej; evaluation of ultrasonograpy and clinical diagnostic scoring in suspected appendicitis, Br.J.Surg:85:3740:1998.

8. Lewis FR, Holeroft JW, et al: Appendicitis: A critical review of diagnosis and treatment in 1000 cases. Ach Surg 1975; 110: 677-684.

9. Ronan ' $\mathrm{O}$ ' conell, " the vermiform appendix," Bailey and Love Short 
practice of surgery, $24^{\text {th }}$ edition, p.12031218.

10. George Mathews John, Siba Prasad Pattanayak, Charan Panda, K. Raja Ram Mohan Rao, Evaluation of Ultrasonography as a Useful Diagnostic Aid in Appendicitis.IJS Vol. 64,No.5, 436-439,2002.

11. Owen TD, William H. Stiff G, Jenkenson LR, Rees B1: Evaluation of Alvarado Score in Acute Appendicitis: Journal of social medicine, Vol.85,87-88: 1992.

12. Bhattacharjee Pk, chowdary T, Roy D: Prospective Evaluation of modified Alvarado Score for diagnosis of acute appendicitis : journal of Indian medical Association, vol,100, No. S; May 2002.

13. GallindoGallego, Fadrique, Neto, Calleja, Fernandej; evaluation of ultrasonograpy and clinical diagnostic scoring in suspected appendicitis, Br.J.Surg:85:3740:1998.

14. Owen TD, William H. Stiff G, Jenkenson LR, Rees B1: Evaluation of Alvarado Score in Acute Appendicitis: Journal of social medicine, Vol. 85,87-88: 1992.

15. Kallan M, Talbot D, Cunliffe WJ, Rich AJ, "Evaluation of modified alvarod Score in diagnosis of Acute Appendicitis : A prospective study “. Ann, RCS of Engl; 76(6): 418-419, 1994.

16. Peiper et al, Actachir Scand, 1982; 148.

17. Elongovan S. Clincial and laboratory findings in acute appendicitis in the elderly, J Am Board Fam Pract 1996: 9: 75-78.

18. Doraiswamy, Br, J. Surg. 1979; 66: 782.

19. Puylaert JBCM: Acute appendicitis-US evaluation using Graded compression, radiology, 158;355-360,1986.

20. Jeffrery RB Jr, Laing FC, Townsend RR. Acute appendicitis: sonagraphic criteria based on 250 cases. Radiology 1988; 167: 327-329.

21. Sudhirkumar Mohanty,Kaushik Si, Evaluation of modified Alvarado score in decreasing negitive appendicectomy rate-our experience, IJS,vol.62;no.5;342-343;2000.

22. Korner H, Sondenaa K, Soreide Ja, Andersen $\mathrm{E}$ et al : the study of negitive appendicectomy rates in Male and Female : age specific and Sexspecific analysis. World J surg 1997;21:313-317. 